\title{
Identifying Effective Fugitive Dust Control Measures for Construction Projects in Korea
}

\author{
Hyun-jun Noh ${ }^{1}$, Seul-ki Lee ${ }^{2}$ and Jung-ho Yu ${ }^{1, *}$ \\ 1 Department of Architecture Engineering, Kwangwoon University, Seoul 01897, Korea; nhj@kw.ac.kr \\ 2 Institute of Construction and Environmental Engineering, Seoul National University, Seoul 08826, Korea; \\ sklee1128@snu.ac.kr \\ * Correspondence: myazure@kw.ac.kr; Tel.: +82-2-940-5564; Fax: +82-2-909-5546
}

Received: 5 March 2018; Accepted: 12 April 2018; Published: 17 April 2018

check for updates

\begin{abstract}
In recent years, the awareness of the seriousness of the damage caused by fugitive dust and the need to manage it have increased. In particular, construction sites comprise $84 \%$ of business places that have reported fugitive dust generation, and they are required to have inspection and management to prevent the occurrence of fugitive dust at construction sites. However, the number of complaints in the construction industry due to fugitive dust has increased. The reason for this increase is the fact that existing control measures are defined based on emission processes rather than construction work types, which makes it difficult to apply fugitive dust control measures to construction sites. Therefore, this research evaluated the effectiveness of fugitive dust control measures for construction sites in Korea through a Delphi study. This Delphi study was conducted in two rounds with 12 experts in an on-site panel, and the factors that were determined to be effective control measures were convergence, the content validity ratio (CVR), and stability. This study's results will be utilized to direct the establishment of future guidelines for fugitive dust control measures based on types of construction work.
\end{abstract}

Keywords: fugitive dust; control measure; construction project; Delphi study

\section{Introduction}

In Korea, $44.3 \%$ of Particles Matter 10 (PM10) are fugitive dust, and one of the main sources of fugitive dust generation is construction work (22\%). Construction sites account for $84 \%$ of the total business places that have reported fugitive dust generation [1]. This implies that fugitive dust generated at construction sites affects air pollution significantly in Korea.

The Clean Air Conservation Act [2] states that fugitive dust at construction sites in Korea must be managed pursuant to Articles 43 and 44 of its enforcement decree and Articles 57 and 58 (installation of facilities to prevent the occurrence of fugitive dust and required measures) of its enforcement rules. The types of construction sites that are subject to the enforcement decree and rules and the actions that such sites must take (e.g., anti-dust layer installation) are specified.

However, problems related to fugitive dust at construction sites arise constantly. The Ministry of Environment [3] has published an increasing number of complaints related to fugitive dust that has thus far totaled 22,827. Of these complaints, 20,797 (91\%, Seoul: $99.4 \%$ ) were made regarding the construction industry. This increasing trend indicates that the current regulations for fugitive dust management at construction sites are ineffective.

Although the current management standards mandate the installation of facilities and measures to prevent fugitive dust, inspections are conducted regarding whether anti-dust covers are installed, or spray water facilities are operated, but their effects are not monitored. Furthermore, guidelines that 
can be referred to by field managers during the planning of measures to suppress the generation of fugitive dust are not sufficient.

Therefore, to understand the current state of fugitive dust management in Korea's construction sites and to support planning efforts for the reduction of fugitive dust generated at construction sites in Korea, this research aims to identify the main types of construction work in which significant fugitive dust is generated and derive an appropriate measure to control fugitive dust. In order to ensure the effectiveness and efficiency of this research, this study is based on construction projects inside urban areas, which cause the most damage to surrounding residents, and sets it scope on the types of construction work that are highly influential in generating fugitive dust in surrounding regions.

The procedure of this study is as follows. In Section 2, we identify the need for research by examining existing studies on fugitive dust at construction sites in Korea. Other nations are also discussed to verify the need for detailed guidelines to establish control measures against fugitive dust. In Section 3, we present the analysis that provides the basis of our Delphi study on the occurrence and influence of fugitive dust based on the type of construction work that generates fugitive dust. Through this study, we aim to remove the redundancy of the control measures against fugitive dust that have been proposed in Korea. Finally, in Section 4, we use the two-round Delphi study results to evaluate the effectiveness of the control measures based on construction work type.

This study enables the planning and establishment of effective fugitive dust control measures based on the type of construction work. Thus, it will also facilitate efficient management and supervision of fugitive dust.

\section{Preliminary Studies}

\subsection{The Severity of Fugitive Dust Generated at Construction Sites}

Dust refers to scattered or floating particles of matter in the air, and if dust is discharged directly without certain outlets, then it is collectively referred to as "fugitive dust". Fugitive dust, also called flowing or scattered dust, is generated in the construction industry and from cement, coal, earthy material, and aggregate factories (Sub-paragraph 6 of Article 2 and Paragraph 1 of Article 43 in the Clean Air Conservation Act). Fugitive dust is classified by particle size (diameter) as being the same as general dust. Most fugitive dust generated at construction sites and from building demolition, coals and oil combustion, industrial processes, and non-paved roads is $10 \mu \mathrm{m}$-diameter or smaller fine dust, which is called PM-10.

Fugitive dust accounts for $44.3 \%$ of all PM-10 generated in Korea, and of this percentage, re-suspended road dust, construction sites, and open areas generate fugitive dust at rates of $45 \%, 22 \%$, and $12 \%$, respectively [1]. The construction industry has the highest reported rate of fugitive dust generation. As of 2015, 84\% of business places reporting fugitive dust production were construction projects, followed by civil projects. In addition, the number of civil complaints involving business places that generate fugitive dust is increasing, and most are from the construction industry [4].

The "2016 Environmental Performance Index" [5], which was co-studied by Yale University and Columbia University, reported that South Korea's air quality is ranked 173 out of 180 nations. In particular, South Korea was ranked 174th in the ultra-fine dust section, which was the same rank as China. The World Health Organization (WHO) set the annual recommended threshold of $20 \mu \mathrm{g} / \mathrm{m}^{3}$ for fine dust concentration and $10 \mu \mathrm{g} / \mathrm{m}^{3}$ for ultra-fine dust concentration. As of 2016, the PM10 pollution level of Seoul was $48 \mu \mathrm{g} / \mathrm{m}^{3}$, which significantly exceeded the $20 \mu \mathrm{g} / \mathrm{m}^{3}$ threshold recommended by the WHO [6]. This level is also much higher than those of other major cities in the nations belonging to the Organization for Economic Cooperation and Development (OECD), such as Los Angeles (LA, $34 \mu \mathrm{g} / \mathrm{m}^{3}$ ) and London $\left(20 \mu \mathrm{g} / \mathrm{m}^{3}\right)$ [6].

The fine dust, which is an air pollutant, adversely affects not only the environment, but also quality of life by damaging people's health and creating discomfort in daily living environments. If no action is taken to reduce fine dust pollution, the social cost of the problem will grow to KRW 12,325 billion 
won by 2024, and the additional deaths caused by fine dust will reach 19,958. Additionally, the number of patients hospitalized due to respiratory diseases will increase up to 11,447 persons, and patients with acute and chronic bronchitis will increase to 811,115 , as estimated by the National Institute of Environmental Research (NIER) [7].

Moreover, the proportion of pneumoconiosis (a disease caused by dust accumulated in the lung) in workers in the construction sector, which are classified as deaths or disasters due to occupation-related diseases, has significantly increased from 3.85\% in 2014 to $10.71 \%$ in 2015, according to the Ministry of Employment and Labor. A survey of 215 construction workers was also conducted about awareness of damage due to fugitive dust [8], and $77.2 \%$ of the total respondents said that "the damage to health due to fugitive dust" was "very high" or "high"; $37.5 \%$ answered that they were stressed due to fugitive dust when asked whether they experienced "work disruption and stress relationship due to fugitive dust". Thus, it is urgently necessary to manage fugitive dust at construction sites in order to reduce work-related diseases for construction workers.

The anxiety that citizens in South Korea experience due to fine dust of high concentration from sources such as the inflow of fine dust from mainland China has increased. Accordingly, the need for and importance of fugitive dust control at construction sites has also increased. In addition, the reduction of fugitive dust at construction sites, which are one of the largest sources of fugitive dust, will contribute to the overall reduction of fugitive dust in South Korea.

\subsection{The Regulations for Fugitive Dust Management at Construction Sites}

In the first stage of our research on improving fugitive dust management in Korea, we compared the fugitive dust management regulations of South Korea and other countries and identified improvements. Our findings are summarized in Table 1.

Table 1. The results of the comparison of South Korea with the other countries (United States of America (USA) and the United Kingdom (UK)).

\begin{tabular}{|c|c|c|}
\hline City & Characteristic & Comparison with Korea's Regulation \\
\hline California (USA) & $\begin{array}{l}\text { The analysis results for fugitive dust management } \\
\text { systems at construction sites demonstrate that the } \\
\text { regulations in the USA define the main generation } \\
\text { sources in construction works and then propose } \\
\text { corrective actions and guidelines to reduce dust } \\
\text { generation. These regulations also recommend that } \\
\text { site managers take additional measures to control } \\
\text { dust generation according to the quantitative } \\
\text { restriction index of dust generation based on dust } \\
\text { concentration monitoring. }\end{array}$ & $\begin{array}{l}\text { There are no management regulations for small-scale } \\
\text { construction projects in Korea. However, } \\
\text { the statistics for construction permits and } \\
\text { construction report (2014-2015) demonstrate that } \\
\text { mid- to large-scale construction projects account for } \\
\text { only } 7 \% \text { to } 8 \% \text { of the total construction projects, } \\
\text { and small-scale construction projects account for } 92 \% \\
\text { to } 93 \% \text {. The results of an investigation regarding the } \\
\text { severity of fugitive dust generation by construction } \\
\text { project size revealed that small-scale construction } \\
\text { sites were more severe producers than mid- to } \\
\text { large-scale projects [9]. They caused frequent civil } \\
\text { complaints, and only post-management was } \\
\text { conducted to take corrective action after the civil } \\
\text { complaints were made. }\end{array}$ \\
\hline London (UK) & $\begin{array}{l}\text { The UK has no regulations related to dust control } \\
\text { measures, but construction permits are approved } \\
\text { only when the control measures planned by the site } \\
\text { manager are in accordance with the authority of the } \\
\text { jurisdiction and regional representatives, and the } \\
\text { control measures for constant environmental } \\
\text { evaluation are regularly updated. The above case } \\
\text { studies in two advanced nations state that sites are } \\
\text { fully liable for fugitive dust generation, and site } \\
\text { managers must take control measures to comply } \\
\text { thoroughly with these regulations. }\end{array}$ & $\begin{array}{l}\text { Construction sites in Korea must perform the control } \\
\text { measures proposed in the Enforcement Rules of the } \\
\text { Clean Air Conservation Act to comply with these } \\
\text { regulations. However, these regulations target all } \\
\text { industries that produce fugitive dust. Thus, } \\
\text { the scope of these regulations is comprehensive, } \\
\text { and control measures are defined according to } \\
\text { emission processes rather than by type of } \\
\text { construction work, which makes it difficult to } \\
\text { determine which control measures are effective and } \\
\text { applicable for each construction work type. }\end{array}$ \\
\hline
\end{tabular}

Seoul (South Korea). Seoul Metropolitan Government inspects construction sites based on whether required control facilities are installed and operated and whether measures are enforced according to "The Standards of Installation of Facilities and Required Measures to Control Fugitive Dust Generation" in Paragraph 4 of Article 58 in the Enforcement Rules of the Clean Air Conservation 
Act [2]. This regulation presents the installation standards for facilities and measures to control fugitive dust according to the 11 emission processes (open air storage and transportation) and 11 businesses that produce fugitive dust (the manufacturing and processing industries of cement, lime, plaster, and cement-related products, and the construction industry) set by the Presidential Decree. The emission processes are limited to ground preparation work, construction and civil work, and landscaping for the construction industry. Based on this regulation, the Seoul Metropolitan Government requires and guides construction sites by district unit. The regulation says that construction sites that are subject to instruction and inspection must have $1000 \mathrm{~m}^{2}$ or larger total floor areas for construction work and $3000 \mathrm{~m}^{2}$ or larger total floor areas for demolition work. The construction sites are then divided into general management construction sites (if the area is between $1000 \mathrm{~m}^{2}$ and 10,000 $\mathrm{m}^{2}$ ) and special management construction sites (if the area is more than 10 times of the minimum size of business places that are subject to reporting fugitive dust generation). The cycle of enforcement is different depending on the construction site size; general management construction sites are inspected at least once per quarter, and special management construction sites are inspected at least once per month.

California (USA). The state of California in the United States of America (USA) is equipped with a system that manages air environments, the South Coast Air Quality Management District (SCAQMD). In particular, construction sites in LA are managed by Rule 403 of the SCAQMD [10,11], and air quality inspectors dispatched by the SCAQMD guide and instruct air quality in the region. Rule 403 controls fugitive dust generated at construction sites regardless of size and type. This rule defines all construction that generates fugitive dust as active operations and construction-related works, such as construction and demolition activities. It proposes requirements that must be adhered to during the execution of works that produce fugitive dust based on these terms.

London (UK). "The control of dust and emissions during construction and demolition Supplementary Planning Guidance" is a guideline that supports the achievement of the environmental goals established independently by London. This rule identifies demolition, earthwork, construction work, and track-outs that produce fugitive dust and evaluates the size and risk level of fugitive dust generated by each work. It also provides sensitivity evaluation data for the surrounding receptors that are affected according to the site distance parameters and provides for the installation of control facilities and measures, but these are only utilized as best practices. Instruction and enforcement are executed by regional offices. The sampling, inspection reports, site inspections, and supervision (in-depth evaluations) are used by regional offices to enforce construction site adherence. In particular, the number and date of site inspections are not open to the public so that they may observe the operation status under normal conditions $[12,13]$.

Upon comparing and analyzing the status of fugitive dust management in different countries, the main difference is that the management systems in other countries apply control measures to achieve quantitative emission targets at construction sites and assess the actual fugitive dust reduction, while also guiding the application of control measures. In addition, since Korea's regulations are not regulations for the construction industry, there is a lack of information about what measures are effective for each construction type. Analyzing the relevant regulations confirmed that concrete guidance was needed not only to establish a fugitive dust control plan for a construction site, but also to apply effective control measures.

\subsection{Previous Studies on Fugitive Dust at Construction Sites}

The literature review of studies on fugitive dust at construction sites are as follows.

Kinsey et al. [14] conducted a study to generate their own emission factor, in addition to the one provided by the United States Environmental Protection Agency (EPA), after seeing fugitive dust generated by mud and dust transported to construction sites as a main emission source. Muleski et al. [15] performed a study to determine an emission factor for fugitive dust generated in 
construction works related to sands, rocks, and soils. Detailed construction task circumstances were used for sampling, and generation sources were identified.

Yu et al. [8] investigated the level of fugitive dust generation (by construction work type and machinery), the level of damage due to fugitive dust (health and physiological effect), and the effect of anti-dust facilities and measures with regard to staff and workers at construction sites in Korea. Seo [16] determined the composition of fine dust and the generation amount from construction sites in urban regions and claimed that most of the fine dust generation came from construction machineries that employed diesel, concrete-related tasks, and site construction work. The immediate execution of physical and passive control measures against fugitive dust at construction sites was the most effective method of reduction. Kohlman-Rabbani et al. [17] derived the dust-generation tasks that influenced workers the most in construction projects in Brazil, which was represented as a typical developing nation. This study identified six dust-generation tasks-mortar and concrete mixing, cleaning, tile cutting, plaster work, wood board work, and sanding — and proved that workers may inhale silica substances found in the dust composition analysis.

Thorpe et al. [18] evaluated the effectiveness of control measures to reduce fugitive dust that occurred in relation to cutting and molding types of construction work. This study claimed that control measures, such as the wet method, spraying water, and using dust-collecting devices, reduced dust by $90 \%$ or more and discovered that the amount of dust generation differed depending on the shape of the blade used for cutting. Evelyn et al. [19] evaluated the effectiveness of control measures to reduce the exposure of workers to quartz at construction sites. The study verified that when the wet method and dust-collecting devices were used, exposure was reduced by $70 \%$, but the most effective single measure in the long term was wearing protective gear for the respiratory organs. As such, the most effective preventive measure against exposure to quartz was usage of protective gear for the respiratory organs, as well as the parallel usage of one or more control measures. Zuo et al. [20] found that the cause of fugitive dust generation at construction sites was due to a lack of awareness on the part of the site managers. This derived from a lack of sense of responsibility, reluctance to spray water because of incorrect perceptions that this was a waste of water, and the underestimation of the effect of fugitive dust on the environment. This study conclusively recommended proactive execution of control measures with a sense of responsibility to prevent excessive spray water and the introduction of regular monitoring and innovative control measures.

Limitation of existing study are summarized in Table 2.

Table 2. Summary of the literature review.

\begin{tabular}{llc}
\hline \multicolumn{1}{c}{ Category } & \multicolumn{1}{c}{ Limitation } & References \\
\hline $\begin{array}{l}\text { The estimation and prediction of } \\
\text { fugitive dust emissions }\end{array}$ & $\begin{array}{l}\text { The emission factor for fugitive dust generated was } \\
\text { derived by setting specific working conditions for } \\
\text { soil and dust-generating work. The main sources and } \\
\text { occurrences are identified, but there is a lack of } \\
\text { suggestions for control measures. }\end{array}$ & {$[14,15]$} \\
\hline $\begin{array}{l}\text { Identification of the main } \\
\text { construction work types that } \\
\text { generate fugitive dust }\end{array}$ & $\begin{array}{l}\text { Work that generated a lot of scattering dust at } \\
\text { construction sites was identified. However, there is a } \\
\text { lack of suggested control measures. }\end{array}$ & {$[8,16,17]$} \\
\hline & $\begin{array}{l}\text { Fugitive dust control measures are presented for } \\
\text { specific construction work and the effect of fugitive } \\
\text { dust reduction is analyzed. However, there are } \\
\text { limitations when evaluating the effectiveness of } \\
\text { control measures for fugitive dust }\end{array}$ & {$[18-20]$} \\
& $\begin{array}{l}\text { specific control measures under the control of certain } \\
\text { construction works. }\end{array}$ & \\
\hline
\end{tabular}

Although construction sites are the main sources of fugitive dust generation, there is insufficient research on fugitive dust at construction sites. Most studies analyzed emissions or identified major construction work types; even if control measures were proposed, they were insufficient to 
reflect the characteristics of a site because they targeted specific construction work or analyzed in controlled conditions.

Therefore, to understand the current state of fugitive dust management in Korean construction sites as the first stage of the improvement of fugitive dust management, this research suggested that the control measures proposed in Korea's fugitive dust management regulations are effective at reducing fugitive dust. In addition, we conducted the study to understand the effectiveness of control measures for each construction work in real construction sites rather than controlled conditions from field experts.

\section{Analysis of Fugitive Dust at Construction Sites}

Generally, the first round of a Delphi study is conducted to develop the survey questionnaire for the next round by gathering various expert opinions on the subject of the study using a focus group interview (FGI). In this research, however, the questionnaire for the Delphi study was developed based on the types of key construction work and fugitive dust control measures identified by a preliminary analysis instead of by conducting an open interview to ensure effective and efficient of the study.

Section 3.1 identifies the types of key construction work based on a survey on fugitive dust generation and impact by type of construction work. Section 3.2 describes the elimination of redundancy and the reclassification of fugitive dust control measures that are currently classified according to the emission process, irrespective of the type of construction work.

\subsection{Construction Work Types That Generate Fugitive Dust}

This research targeted the main types of construction that produce high amounts of fugitive dust or influence the surrounding regions rather than targeting all construction work types. To derive the main construction work type in this research, we surveyed "the level of fugitive dust generation per unit area (Occurrence)" and "the impact due to fugitive dust generation (Influence)" of each construction work type. We conducted the survey on the 21 construction work types (from temporary work to demolition work) defined in the "Construction Work Standard Specifications" [21] provided by the Ministry of Land, Infrastructure, and Transport.

Because the scope of this research is the fugitive dust generated in the construction phase, the data were obtained from a sample of experienced construction managers and quality managers. The questionnaire was sent by e-mail through the project directors of each organization. The survey was conducted between 11 July and 12 July 2017; a total of 30 responses were received, all of which were valid and used for the analysis. Among the 30 respondents, 14 were from construction supervision organizations, 9 were from construction management organizations, and 7 were from constructor organizations.

Occurrence and influence were measured on a 7-point Likert scale ranging from "strongly disagree" to "strongly agree". The descriptive statistics of the respondents' characteristics are shown in Table 3.

Table 3. Characteristics of the respondents $(n=30)$.

\begin{tabular}{lccc}
\hline & Measure & Frequency & $\%$ \\
\hline $\begin{array}{l}\text { Sector of the } \\
\text { respondent's } \\
\text { organization }\end{array}$ & Construction Manager & 9 & $30.0 \%$ \\
& Construction & 14 & $46.7 \%$ \\
& Contractor & 7 & $23.3 \%$ \\
\hline \multicolumn{2}{c}{ Total } & 30 & $100 \%$ \\
\hline \multicolumn{2}{c}{ Respondent's average experience } & Approx. 21.6 years
\end{tabular}

The analysis results are shown in Table 4. 
Table 4. Results of evaluating the occurrence and influence of fugitive dust.

\begin{tabular}{cccccc}
\hline \multirow{2}{*}{ No. } & Construction Activities & \multicolumn{2}{c}{ Occurrence } & \multicolumn{2}{c}{ Influence } \\
\cline { 3 - 6 } & & Mean & SD & Mean & SD \\
\hline 1 & Temporary work & 3.90 & 1.83 & 3.80 & 1.83 \\
2 & Earth work & 5.80 & 1.47 & 6.03 & 1.07 \\
3 & Foundation work & 4.63 & 1.40 & 4.77 & 1.38 \\
4 & Concrete work & 4.63 & 1.59 & 4.90 & 1.35 \\
5 & Steel construction & 2.53 & 1.01 & 2.70 & 1.26 \\
6 & Masonry work & 3.23 & 1.38 & 3.10 & 1.24 \\
7 & Stone masonry work & 4.47 & 1.43 & 4.23 & 1.59 \\
8 & Tile and terracotta work & 3.17 & 1.26 & 2.70 & 1.26 \\
9 & Carpentry work & 3.37 & 1.22 & 3.07 & 1.28 \\
10 & Waterproof and damp proofing work & 2.77 & 1.33 & 2.43 & 1.22 \\
11 & Roofing & 2.47 & 1.22 & 2.43 & 1.14 \\
12 & Metal work & 2.57 & 1.10 & 2.53 & 1.20 \\
13 & Exterior wall construction & 3.70 & 1.49 & 3.43 & 1.57 \\
14 & Plaster work & 3.40 & 1.07 & 3.13 & 1.20 \\
15 & Ondol construction (Panel heating) & 2.53 & 1.07 & 2.43 & 1.07 \\
16 & Glazing, doors, and windows & 1.77 & 0.73 & 1.73 & 0.64 \\
17 & Painting work & 3.90 & 1.47 & 3.97 & 1.61 \\
18 & Interior finishing work & 3.30 & 1.32 & 2.90 & 1.16 \\
19 & Landscaping & 3.53 & 1.31 & 3.23 & 1.57 \\
20 & Fireproofing and insulation work & 3.33 & 1.42 & 3.00 & 1.44 \\
21 & Demolition work & 5.97 & 1.35 & 5.77 & 1.45 \\
\hline
\end{tabular}

Analysis was conducted with the $X$-axis as the level of generation and the $Y$-axis as the level of impact. The results showed that these two were proportional with each other. The highest levels of generation and impact were "demolition work" and "earth work", which occurred in a large outside area. Thus, the generation and impact of fugitive dust in these two categories were overwhelmingly high compared to other construction work types. Earth work, foundation work, and concrete work had relatively high impact levels compared with their generation level. Because these construction work types produced finer dust than other work types, they spread more fugitive dust farther. Thus, more detailed management is needed for these work types.

This study divided construction work types into four quadrants centered on the median values of generation (see Figure 1). The impact levels and construction work types in Quadrant 1 were defined as the main construction work types. Accordingly, the following 10 construction work types were derived from the initial 21: temporary work, earth work, foundation work, concrete work, stone masonry work, exterior wall construction, plaster work, painting work, landscaping, and demolition work. 


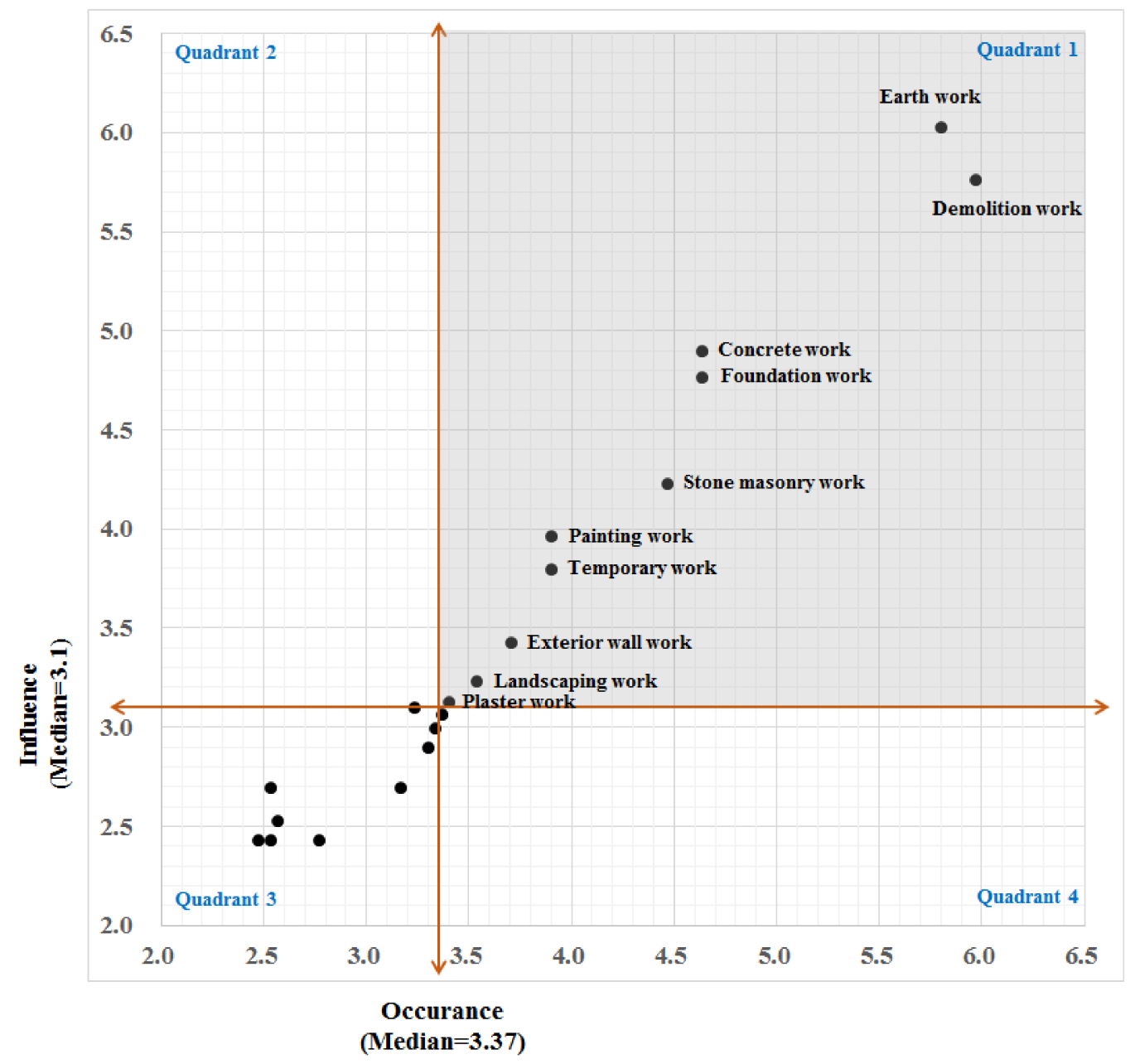

Figure 1. Occurrence-influence Matrix.

\subsection{Classified Fugitive Dust Control Measure at Construction Sites}

In Korea, business places that produce fugitive dust are managed through "The Standards of Facility Installation and Required Measures to Control Fugitive Dust Generation" to control the generation of fugitive dust as in Paragraph 4 in Article 58 of the Enforcement Rules in the Clean Air Conservation Act [2]. This regulation presents control measures that should be performed according to the 11 processes that generate fugitive dust, which are not related to particular construction work types. Control measures are defined in a duplicate manner.

This study derived a total of 12 control measures against fugitive dust, as presented in Table 5 , after removing the duplicate control measures defined in the regulations prior to deriving effective control measures for each construction work type. In addition, these 12 control measures can be largely classified into the "installation of facilities for controlling generation of fugitive dust", "operation of vehicles, construction machinery and equipment for controlling the generation of fugitive dust", and "worker's activities to control fugitive dust generation". 
Table 5. Fugitive dust control measures.

\begin{tabular}{|c|c|c|c|}
\hline \multicolumn{3}{|c|}{ Control Measure } & Definition \\
\hline \multirow{4}{*}{ Installation of Facility } & 1 & Dustproof facility & Dustproof net, wall, and cover \\
\hline & 2 & Dust-collecting facility & Facilities that filter dust and purify air to the outside. \\
\hline & 3 & Water spray facility & Facilities that spray water on transport vehicles. \\
\hline & 4 & Wheel-washing facility & Facilities that remove dirt, etc. from the wheels of vehicles. \\
\hline \multirow{4}{*}{$\begin{array}{l}\text { Operation of Vehicles } \\
\text { and Equipment }\end{array}$} & 5 & Control of load capacity & Control of load capacity and installation of a cover to \\
\hline & 6 & Low-speed driving & $\begin{array}{l}\text { prevent leakage. } \\
\text { Prevent dust from being blown by the wind. }\end{array}$ \\
\hline & 7 & Horizontal Loading & Prevent the generation of fugitive dust due to collision \\
\hline & 8 & Road pavement & Prevent re-splashing of dust when driving on unpaved roads. \\
\hline \multirow{4}{*}{ Activity of worker } & 9 & Spraying water & Water-spraying actions to reduce fugitive dust \\
\hline & 10 & Cleaning & If it is not possible to install a mobile dust-collecting facility, \\
\hline & 11 & Indoor work & $\begin{array}{l}\text { clean the work site with a genuine cleaning vehicle. } \\
\text { Work indoors. }\end{array}$ \\
\hline & 12 & $\begin{array}{l}\text { The suspension of work when } \\
\text { wind speed was high }\end{array}$ & When wind speed is more than $8 \mathrm{~m}$ per second, prohibit work. \\
\hline
\end{tabular}

\section{Fugitive Dust Control Measures According to Construction Work Type}

\subsection{Methodology}

\subsubsection{Overview}

The reason for using the Delphi technique in this research is as follows. First, we chose a qualitative method to understand the effectiveness of the control measures for each construction work in real construction sites rather than controlled conditions from field experts. Second, we chose the Delphi technique, which was applied to the statistical method to overcome the shortcomings of the qualitative methods, which are difficult to quantify in results and maintain neutrality in interpretation. Third, we determined that the use of the Delphi technique is appropriate for this research. The Delphi technique is especially useful when there is a lack of prior research, and expert opinion is the most important. Practically, previous studies on fugitive dust at construction sites was lacking and field experts' opinions were important to understanding the effectiveness of control measures for each construction work in a real construction site setting.

The Delphi technique, which was developed by the Rand Corporation in the United States, is a method of generating accurate predictions by obtaining responses from experts on a specific issue, summarizing the responses, and giving the experts feedback on the responses [22]. The Delphi technique is used to draw consensus among geographically separated experts and was developed to derive expert opinions to predict specific problems and solve problems that require collective judgment [23]. This technique was developed based on the quantitative objective method that "judgment made by two people is more accurate than those made by one person" and the principle of democratic decision-making, which is that "majority opinions are more accurate than minority opinions". This method was found to obtain accurate estimations if the group's estimation is derived by a series of expert groups and is therefore likely to include a range of correct answers. It has three basic features: "iteration of rounds and controlled feedback," "panel anonymity", and "statistical group response" [24].

The Delphi execution procedure is conducted through multiple rounds of surveys to reach consensus in experts' opinions: collecting experts' suggestions regarding opposable events, summarizing the suggestions, giving the experts feedback, and facilitating them during the second round of deliberation. For the Delphi technique, the optimal number of rounds is between two and five. In the first round, an open-type survey is conducted, and in the second round, a re-survey is conducted after extracting structured questionnaires based on the first round's open-type survey. In the third round, the consensus trend and variability of the responses from the panelists collected in the second round are identified, and a re-survey is conducted with the notation of respondent's own response in the second round along with the consensus trend and variability of the questionnaire. 
In the first round, researchers have generally gathered various expert opinions using FGI. In this research, however, we conducted a preliminary analysis to develop a questionnaire for a Delphi study, instead of an open interview, to ensure effective and efficient of the study.

\subsubsection{Data Collection}

Dalkey [25] found that at least 10 expert panelists were needed to minimize the error of the average group in the correlation between panel size and maximization of the reliability of the group. Anderson [26] found that useful results can be obtained with only 10-15 experts in a small group.

To minimize errors and maximize reliability, selection criteria for the panel included representativeness, appropriateness, and expert knowledge in field management. To ensure the panel was capable of evaluating the effectiveness of the fugitive dust control measures specified in the regulations, panel members were selected under the assumption that they have a variety of construction-site experience and either engage in planning for the application of fugitive dust control measures or perform quality-control work.

The panel consists of 12 experts-five with experience in quality control and seven with construction-management experience. The panelists' average career length is 25.5 years, with a minimum career length of 10 years. The recruitment was conducted over the phone. Once panel members were selected, researchers requested that they participate in two rounds of a survey process. The survey was conducted with the 12 people who were willing to participate following the phone screening.

A Delphi study was conducted in the present study to evaluate the effectiveness of the control measures against fugitive dust according to construction work type between August and December of 2017. Round 2 of the Delphi study was conducted to collect final opinions based on the Round 1 of the Delphi study to collect experts' opinions about the effectiveness of control measures according to construction work type and the Round 1's Delphi study results. Round 1 and Round 2 questionnaires were sent to field experts via email, and responses were taken through email replies.

\subsubsection{Questionnaire Development}

Delphi Round 1. The questionnaire for the Delphi study was constructed using the analysis results in Section 3. In Round 1, the effectiveness of the 12 control measures in 10 main construction processes was evaluated by 12 experts who had worked in the industry for an average of 26 years. The effectiveness of control measure was measured on a 7-point Likert scale ranging from "strongly disagree" to "strongly agree".

Delphi Round 2. The survey questionnaire was re-structured based on the information collected in round 1. First, the calculated average of the experts' first responses was displayed as an "Md". Second, a response range within the median $50 \%$ that reflected the response trend of the other respondents was marked by an empty bracket ([]). Finally, the scores that were selected by each respondent in Round 1 were marked by asterisk (*). After checking the results of Round 1 , we asked the respondents to evaluate the questionnaire again. If the score selected by the respondent was out of the answer range of the median $50 \%$, then we asked the respondents to write the reason.

\subsubsection{Consensus Criteria}

Because the criteria that determine whether the results of the experts' responses are effective control measures were reached in consensus, this study utilized stability, convergence (width of the response range), and the content validity ratio (CVR; the position of the response range). The concepts of the evaluation elements are as follows:

- Stability 
When the response is highly consistent as a result of few differences between the survey responses of the panelists in the repeated survey process, it is said that stability is ensured, which is measured by the contingent valuation $(\mathrm{CV})$ :

$$
\mathrm{CV}=\frac{S D}{M}
$$

where $\mathrm{CV}$ is the coefficient of variation, $S D$ is the standard deviation, and $M$ is the mean

If the $C V$ is less than 0.5 , no additional survey is needed. If the $C V$ is $0.5-0.8$, it indicates relative stability. However, if the CV is more than 0.8 , an additional survey is needed [27-29].

\section{- Convergence}

Convergence is used to evaluate a convergence of opinions on a single point. It utilizes the quartile deviation (see Equation (2)). The quartile deviation is defined as being half the interquartile range (IQR). The IQR is an index that represents a response trend, which refers to a range that corresponds to the median $50 \%$ of all response values. If the IQR value is less than one, then it means that more than $50 \%$ of the responses are distributed within one point [30]. In general, if the IQR value is less than two, then it is interpreted as a consensus [30-33]. In this study, when the convergence value of the expert panel is less than one, then it is regarded as consensus of opinion.

$$
\text { CONV. }=\frac{Q_{3}-Q_{1}}{2}
$$

where CONV. is the quartile deviation; the closer the value is to zero, the more valid the item. $Q_{1}$ is the first quartile, or the lower $25 \%$, and $Q_{3}$ is the third quartile, or the upper $25 \%$.

\section{- Content Validity Ratio (CVR)}

The CVR is a means to quantify a level of opinion consensus by panelists who are equipped with expertise in a certain field. It is a concept proposed by Lawshe [34]. The response panel evaluates whether each of the items is "essential" or not, and if the majority of the respondents said that the item was essential, the content is considered valid. In other words, the greater the number of panelists that consider an item to be essential (more than 50\%), the larger the content validity is. the functions of CVR based on this assumptions is shown Equation (3).

$$
\mathrm{CVR}=\frac{N e-\frac{N}{2}}{\frac{N}{2}}
$$

where CVR is the content validity ratio $(-1 \sim+1), N$ is the total number of panelists, and $N e$ is the number of panelists indicating 'essential' (In the case of the 7-point Likert scale, the number of panelists that responded with 5 points or more).

If less than $50 \%$ of panelists consider an item to be essential, then the CVR is negative, and if half of them answer that it is essential, then the CVR is zero. If more than $50 \%$ of panelists answer that an item is essential, then the CVR is positive. The CVR presents the minimum value according to the number of panelists [31]. When the CVR is more than the minimum value, the item is considered to have content validity. In this study, the number of respondents was 12 . Thus, the minimum value of the CVR was 0.56 .

\subsection{Results}

The evaluation results for the effectiveness of the 12 control measures by 10 construction work types were as follows (see Appendix A).

The standard deviation and convergence in Round 2 tended to decrease compared to those in Round 1, and the items whose convergence satisfied the consensus level increased from 27 items in Round 1 to 37 items in Round 2. This result meant that field experts agreed with their opinions. 
In addition, the stability of all items in Round 2 was less than 0.8 , which verified that no additional survey was needed.

The effectiveness level for the control measures in each of the construction work types showed that temporary work (5.14), earthwork (5.38), foundation work (5.17), and demolition work (5.98) were relatively high, whereas exterior wall work (3.93), plaster work (3.66), and paint work (3.69) were relatively low. Cleaning, wheel-washing facilities, spray water facilities, and spray water were the control measures for which there was the most consensus that they were effective, whereas the effectiveness of anti-dust facilities and indoor work as control measures reached less of a consensus.

Temporary work. The control measures that reached consensus were spraying water, water spray facilities, the suspension of work when wind speed was high, and wheel-washing facilities. The selected control measures were work types that required high amounts of material transportation, such as loading and unloading, where high amounts of fugitive dust were generated. Note that "suspension of work when wind speed is high" was agreed upon as an effective control measure, but some experts said that the suspension of work due to wind speed was difficult. Other control measures were high priority but did not reach consensus. Road pavement was effective in the prevention of fugitive dust, but it may not be possible to apply it depending on the site conditions, and anti-dust facilities may not solve the fugitive dust problem in many cases due to the typically wide area of construction work.

Earth work. The effectiveness of these control measures was high overall. The measures that reached consensus as being effective were wheel-washing facilities, spray water, water spray facilities, road pavement, control of load capacity, horizontal loading, and low-speed driving. Earth work is a construction work type with high generation and impact of fugitive dust, because fugitive dust is generated significantly in soil and aggregate stocking, loading and unloading, and transportation. Vehicles and construction machinery that transport soils and aggregates must be managed. The control measures that had a high mean value of effectiveness but did not reach consensus were the installation of anti-dust facilities, which is effective but requires difficult installation, and cleaning, which may increase the generation of dust with respect to earth work.

Foundation work. The effective control measures that reached consensus were wheel-washing facilities, spray water facilities, road pavement, and low-speed driving. Of these, spray water facility was regarded as highly effective in the prevention of fugitive dust, but some experts said that it was difficult to employ due to the movement of machinery and equipment.

Concrete work. The effective control measures that reached consensus were wheel-washing facilities and cleaning. In this type of construction work, most fugitive dust is generated during concrete pouring. Thus, the spread of fugitive dust generated during this work to surrounding areas occurs due to the movements of nearby construction equipment. Control measures such as the installation of an anti-dust facility or the suspension of work during high wind speeds were effective, but they did not reach consensus because an anti-dust facility is difficult to install due to cost issues and suspending work due to wind speeds is not possible in many cases.

Stonemasonry work. The effective control measures that reached consensus were dust-collecting facilities and cleaning. Although stonemasonry materials are ordered according to required dimensions, they are often cut on-site, generating dust. The experts answered that dust-collecting facilities were necessary not only for the prevention of dust from spreading to the outside but also for discharging purified air after filtering out the dust to control fugitive dust generated during this work.

Exterior wall work and plaster work. No control measures reached consensus. Both of these construction work types were evaluated as having low generation and impact of fugitive dust, because most exterior wall work involves the installation of pre-fabricated and transported materials, and plaster work involves a high proportion of indoor work. Furthermore, the evaluation results on the effectiveness of the 12 control measures were low overall. This implies that the control measures proposed in the regulations were not appropriate for exterior wall work and plaster work. Note that 
the control measures did not reach consensus, but high priority was placed on cleaning for exterior wall work and cleaning and indoor work for plaster work.

Painting work. This work may impact not only construction workers but also the surrounding regions because it may generate ultra-fine dust, including volatile organic compounds (VOCs) that affect the human body adversely if the spray method is used. The effective control measure that reached consensus was the suspension of work during fast wind speeds, but the evaluation results of the effectiveness of the 12 control measures were low overall. Furthermore, the above measure was deemed difficult to apply to actual work because painting cannot be done during strong winds or excessive ventilation conditions due to its innate characteristics.

Landscaping work. Fugitive dust is generated mainly during loading and unloading, as well as during the transportation of soils and trees. The effective control measures that reached consensus were spraying water, cleaning, control of load capacity, horizontal loading, and road pavement.

Demolition work. This was one of the main control sectors because it had the highest generation and impact of fugitive dust, but is also the most effectively controlled through appropriate measures. Because demolition work is separately designated for business places and subject to reporting according to the regulations, including the control measures utilized in this study, all control measures except for indoor work were agreed to be effective.

\subsection{Discussions}

The comprehensive analysis and causes of Delphi results are as follows.

First, convergence was decreased and the number of effective control measures that reached consensus was increased, which may be interpreted as the results of Delphi Round 2 reaching consensus. However, our consensus level was low compared to that of other studies that utilized a Delphi technique because effective control measures differ depending on site circumstances due to the characteristics of the construction industry.

Second, the "other processes" in the "Standards of Control Facility and Measure to Prevent Fugitive Dust" recommend that painting work require the "installation of a dustproof net" and "indoor work," whereas only the measure "suspension of work during high wind speeds" reached consensus in the present study. In the evaluation results, regarding the effectiveness of control measures, the "installation of a dustproof facility" and "indoor work" measures were highly effective, but their content validity was low, which was why they were not selected. In this regard, some experts expressed that a large area of work was difficult to control using anti-dust facilities, and the installation of anti-dust facilities may be difficult depending on site conditions.

Third, comparing the results of averaged and agreed-upon effective control measures by construction work type showed that temporary work, earth work, foundation work, and demolition work were high, whereas those of exterior wall work, plaster work, and painting work were lower. The reason for these results was because most control measures of fugitive dust proposed in the "Standards of Control Facility and Measure to Prevent Fugitive Dust" targeted external works.

Fourth, cleaning, wheel-washing facilities, spray water facilities, water spraying, and road pavement were selected as the most effective control measures of the 12 control measures. However, these control measures are general measures to prevent fugitive dust generated by movements of vehicles and construction machinery and equipment and cannot be viewed as control measures that reflect the characteristics of a particular construction work type. Despite being effective control measures, they may also be prohibitive due to the cost burden and more easily applicable control measures that exist.

\section{Conclusions}

Although inspection and management are conducted to prevent the generation of fugitive dust at construction sites, the number of civil complaints against the construction industry is still increasing. This is because business places that comply with the regulations were defined on the basis of their size, 
and control measures were defined by the dust emission process without considering construction work types and may have been difficult to apply as control measures for fugitive dust generation at construction sites.

Therefore, this research identified effective fugitive dust control measures for construction projects in Korea using a Delphi study. The main findings of this study's results are as follows.

First, this study derived 10 construction work types that were the main targets of fugitive dust control by analyzing the generation and impact of fugitive dust: temporary work, earth work, foundation work, concrete work, stone masonry work, exterior wall construction, plaster work, painting work, landscaping, and demolition work. Second, we confirmed that the reason for the low level of consensus is that the effective control measures may be different depending on the characteristics of the construction site, such as country, location, scale, etc. Also, although control measures, which are included in the regulation, are effective for controlling fugitive dust, the reason for the low level of consensus is that the currently enforced regulations target the entire industry, and the characteristics of the construction work at construction sites were not reflected. Therefore, in future research, the way in which the characteristics of the construction site affect control efforts should be analyzed and measures to effectively control fugitive dust at construction sites should be proposed. Third, for some construction work types, such as painting work, which was mostly done indoors, the generation and impact of fugitive dust may be low, but may have a worse effect on construction workers because it generates ultra-fine dust, including VOC. Thus, it is urgently necessary to provide a measure of fugitive dust control for construction work performed indoors. Finally, in actual construction projects, easily applicable control measures may be selected over effective control measures due to cost issues. To solve this problem, detailed control measures to enable careful management in accordance with the characteristics of each work type should be proposed through analysis of the generation pattern of fugitive dust by construction work type. Moreover, all stakeholders should be aware that planning efforts to control fugitive dust are necessary and essential actions rather than a measure taken for show.

The expected effects of this study are as follows.

First, the execution of effective control measures for fugitive dust based on main construction work types can increase construction site management efficiency from the site manager's perspective. Second, the identification of effective control measures of fugitive dust by main construction work type can increase efficiency and guide the inspection of construction sites by authorities with jurisdiction. Third, the study results can provide foundational data to indicate problems in the enforcement regulations in relation to fugitive dust control at construction sites and encourage the modification of the enforcement regulations.

This study evaluated the effectiveness of control measures based on field experts' experience and was restricted to Korean construction sites and regulations. Due to these limitations, future research should include analysis of the effects of fugitive dust control measures based on site characteristics, such as country, region, and size; the identification of various fugitive dust control measures for specific types of construction work by analyzing various technologies and regulations of fugitive dust control in developed countries; the classification of the stop measures based on the size of the construction site and type of construction work; and the effects of the measures using experiments.

Acknowledgments: This research was supported by a grant (17CTAP-C114926-02) from the Infrastructure and Transportation Technology Promotion Program funded by Ministry of Land, Infrastructure, and Transport of the Korean government.

Author Contributions: Jung-ho Yu designed the research and provided guidance in the research process; Hyun-jun Noh conducted literature review and collected data; Seul-ki Lee conducted to analyze data and interpreted results. All authors read and approved the final manuscript.

Conflicts of Interest: The authors declare no conflicts of interests. 


\section{Appendix A}

Table A1. Results of the Delphi.

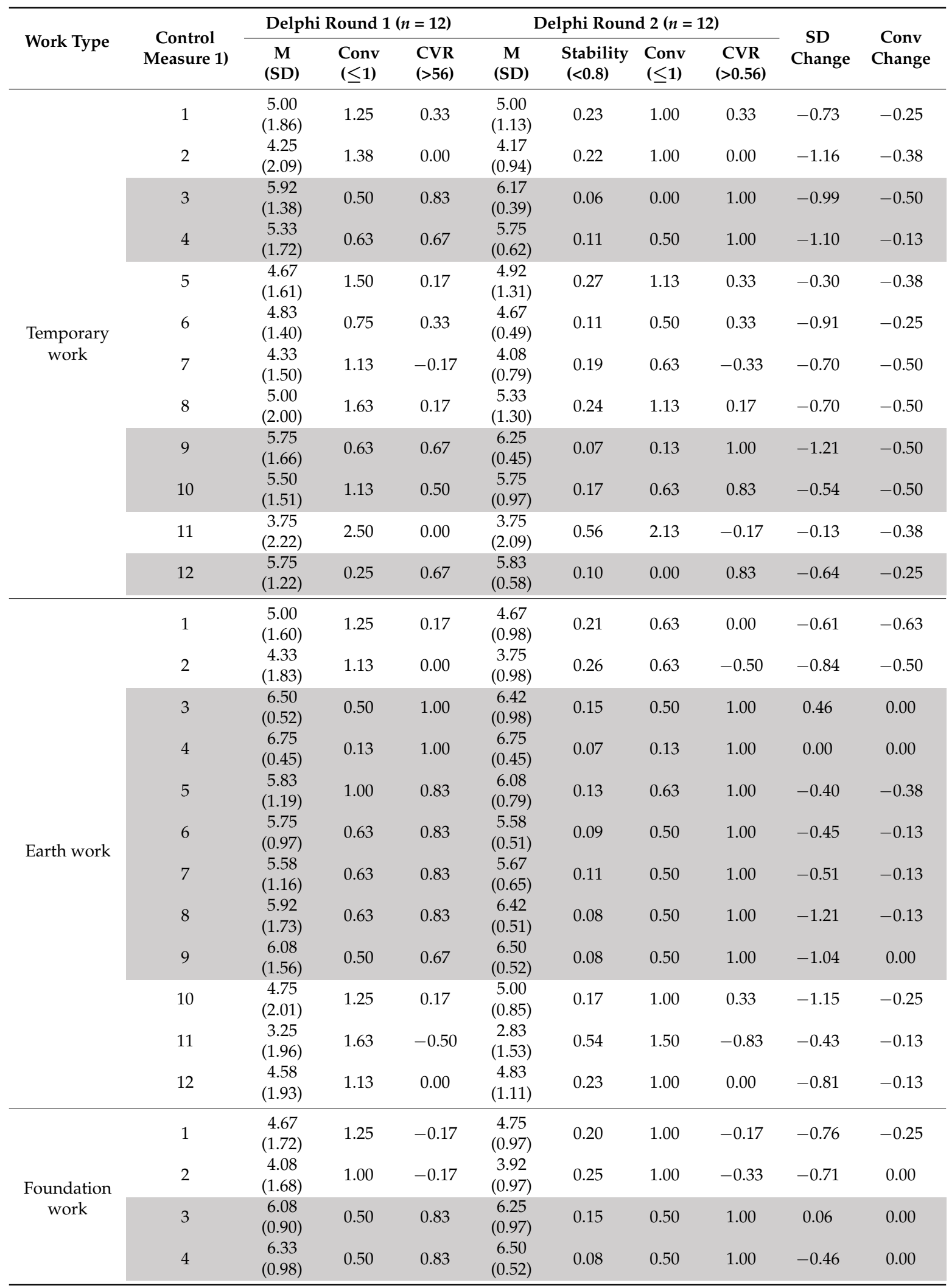


Table A1. Cont.

\begin{tabular}{|c|c|c|c|c|c|c|c|c|c|c|}
\hline \multirow{2}{*}{ Work Type } & \multirow{2}{*}{$\begin{array}{c}\text { Control } \\
\text { Measure 1) }\end{array}$} & \multicolumn{3}{|c|}{ Delphi Round $1(n=12)$} & \multicolumn{4}{|c|}{ Delphi Round $2(n=12)$} & \multirow{2}{*}{$\begin{array}{l}\text { SD } \\
\text { Change }\end{array}$} & \multirow{2}{*}{$\begin{array}{l}\text { Conv } \\
\text { Change }\end{array}$} \\
\hline & & $\begin{array}{c}\text { M } \\
\text { (SD) }\end{array}$ & $\begin{array}{l}\text { Conv } \\
(\leq 1)\end{array}$ & $\begin{array}{l}\text { CVR } \\
(>56)\end{array}$ & $\begin{array}{c}\mathrm{M} \\
\text { (SD) }\end{array}$ & $\begin{array}{c}\text { Stability } \\
(<0.8)\end{array}$ & $\begin{array}{l}\text { Conv } \\
(\leq 1)\end{array}$ & $\begin{array}{c}\text { CVR } \\
(>0.56)\end{array}$ & & \\
\hline & 5 & $\begin{array}{c}5.33 \\
(1.56)\end{array}$ & 1.50 & 0.33 & $\begin{array}{c}5.42 \\
(1.16)\end{array}$ & 0.21 & 0.75 & 0.50 & -0.39 & -0.75 \\
\hline & 6 & $\begin{array}{c}5.50 \\
(1.24)\end{array}$ & 0.63 & 0.67 & $\begin{array}{c}5.50 \\
(0.52)\end{array}$ & 0.09 & 0.50 & 1.00 & -0.72 & -0.13 \\
\hline & 7 & $\begin{array}{c}4.92 \\
(1.62)\end{array}$ & 1.13 & 0.17 & $\begin{array}{c}4.92 \\
(0.79)\end{array}$ & 0.16 & 0.63 & 0.33 & -0.83 & -0.50 \\
\hline & 8 & $\begin{array}{c}5.67 \\
(1.50)\end{array}$ & 1.00 & 0.67 & $\begin{array}{c}5.92 \\
(0.79)\end{array}$ & 0.13 & 0.63 & 1.00 & -0.70 & -0.38 \\
\hline & 9 & $\begin{array}{c}4.92 \\
(2.07)\end{array}$ & 2.00 & 0.17 & $\begin{array}{c}5.08 \\
(1.78)\end{array}$ & 0.35 & 2.00 & 0.17 & -0.28 & 0.00 \\
\hline & 10 & $\begin{array}{c}4.92 \\
(1.98)\end{array}$ & 1.13 & 0.33 & $\begin{array}{c}5.25 \\
(0.97)\end{array}$ & 0.18 & 1.00 & 0.33 & -1.01 & -0.13 \\
\hline & 11 & $\begin{array}{c}3.83 \\
(2.33)\end{array}$ & 2.50 & 0.00 & $\begin{array}{c}3.58 \\
(2.11)\end{array}$ & 0.59 & 1.75 & 0.00 & -0.22 & -0.75 \\
\hline & 12 & $\begin{array}{c}5.08 \\
(1.78)\end{array}$ & 1.00 & 0.33 & $\begin{array}{c}5.00 \\
(1.04)\end{array}$ & 0.21 & 1.00 & 0.33 & -0.74 & 0.00 \\
\hline \multirow{12}{*}{$\begin{array}{l}\text { Concrete } \\
\text { work }\end{array}$} & 1 & $\begin{array}{c}4.75 \\
(1.91)\end{array}$ & 1.63 & 0.17 & $\begin{array}{c}4.42 \\
(1.24)\end{array}$ & 0.28 & 1.13 & 0.00 & -0.67 & -0.50 \\
\hline & 2 & $\begin{array}{c}4.25 \\
(1.96)\end{array}$ & 1.63 & 0.00 & $\begin{array}{c}4.17 \\
(1.24)\end{array}$ & 0.30 & 1.13 & -0.17 & -0.72 & -0.50 \\
\hline & 3 & $\begin{array}{c}4.42 \\
(1.68)\end{array}$ & 0.75 & -0.17 & $\begin{array}{c}4.50 \\
(1.24)\end{array}$ & 0.28 & 0.50 & 0.00 & -0.44 & -0.25 \\
\hline & 4 & $\begin{array}{c}5.50 \\
(1.57)\end{array}$ & 0.63 & 0.67 & $\begin{array}{c}5.67 \\
(0.49)\end{array}$ & 0.09 & 0.50 & 1.00 & -1.07 & -0.13 \\
\hline & 5 & $\begin{array}{c}4.75 \\
(1.76)\end{array}$ & 1.63 & 0.17 & $\begin{array}{c}4.58 \\
(1.31)\end{array}$ & 0.29 & 1.50 & 0.17 & -0.45 & -0.13 \\
\hline & 6 & $\begin{array}{c}4.75 \\
(1.60)\end{array}$ & 1.13 & 0.17 & $\begin{array}{c}4.75 \\
(0.97)\end{array}$ & 0.20 & 0.63 & 0.17 & -0.64 & -0.50 \\
\hline & 7 & $\begin{array}{c}4.00 \\
(2.00)\end{array}$ & 1.25 & -0.17 & $\begin{array}{c}3.75 \\
(0.87)\end{array}$ & 0.23 & 0.63 & -0.50 & -1.13 & -0.63 \\
\hline & 8 & $\begin{array}{c}4.75 \\
(1.76)\end{array}$ & 1.13 & 0.17 & $\begin{array}{c}5.00 \\
(0.85)\end{array}$ & 0.17 & 1.00 & 0.33 & -0.91 & -0.13 \\
\hline & 9 & $\begin{array}{c}4.42 \\
(2.07)\end{array}$ & 1.75 & -0.17 & $\begin{array}{c}4.42 \\
(1.38)\end{array}$ & 0.31 & 1.50 & 0.00 & -0.69 & -0.25 \\
\hline & 10 & $\begin{array}{c}5.58 \\
(1.56)\end{array}$ & 1.13 & 0.50 & $\begin{array}{c}5.67 \\
(0.89)\end{array}$ & 0.16 & 0.50 & 0.83 & -0.68 & -0.63 \\
\hline & 11 & $\begin{array}{c}3.75 \\
(2.18)\end{array}$ & 1.50 & 0.00 & $\begin{array}{c}3.83 \\
(1.70)\end{array}$ & 0.44 & 1.50 & 0.00 & -0.48 & 0.00 \\
\hline & 12 & $\begin{array}{c}4.42 \\
(1.73)\end{array}$ & 0.75 & 0.17 & $\begin{array}{c}4.67 \\
(0.65) \\
\end{array}$ & 0.14 & 0.50 & 0.17 & -1.08 & -0.25 \\
\hline \multirow{12}{*}{$\begin{array}{l}\text { Stone } \\
\text { Masonry } \\
\text { work }\end{array}$} & 1 & $\begin{array}{c}4.33 \\
(1.92)\end{array}$ & 1.63 & 0.17 & $\begin{array}{c}4.42 \\
(1.24)\end{array}$ & 0.28 & 1.13 & 0.00 & -0.68 & -0.50 \\
\hline & 2 & $\begin{array}{c}5.33 \\
(1.87)\end{array}$ & 1.13 & 0.50 & $\begin{array}{c}5.42 \\
(1.24)\end{array}$ & 0.23 & 0.63 & 0.83 & -0.63 & -0.50 \\
\hline & 3 & $\begin{array}{c}4.08 \\
(1.68)\end{array}$ & 1.13 & 0.00 & $\begin{array}{c}4.08 \\
(1.24)\end{array}$ & 0.30 & 1.00 & 0.00 & -0.44 & -0.13 \\
\hline & 4 & $\begin{array}{c}3.58 \\
(1.73)\end{array}$ & 0.50 & -0.67 & $\begin{array}{c}3.50 \\
(0.52)\end{array}$ & 0.15 & 0.50 & -1.00 & -1.21 & 0.00 \\
\hline & 5 & $\begin{array}{c}4.42 \\
(1.24)\end{array}$ & 0.50 & 0.00 & $\begin{array}{c}4.50 \\
(0.67)\end{array}$ & 0.15 & 0.50 & 0.17 & -0.57 & 0.00 \\
\hline & 6 & $\begin{array}{c}4.25 \\
(1.36)\end{array}$ & 0.63 & -0.33 & $\begin{array}{c}4.33 \\
(0.65)\end{array}$ & 0.15 & 0.50 & -0.17 & -0.71 & -0.13 \\
\hline & 7 & $\begin{array}{c}4.92 \\
(1.73)\end{array}$ & 1.25 & 0.17 & $\begin{array}{c}4.92 \\
(1.00)\end{array}$ & 0.20 & 1.00 & 0.33 & -0.73 & -0.25 \\
\hline & 8 & $\begin{array}{c}4.67 \\
(1.50)\end{array}$ & 1.13 & 0.17 & $\begin{array}{c}5.00 \\
(0.85)\end{array}$ & 0.17 & 1.00 & 0.33 & -0.64 & -0.13 \\
\hline & 9 & $\begin{array}{c}4.33 \\
(2.02)\end{array}$ & 1.63 & 0.00 & $\begin{array}{c}4.50 \\
(1.24)\end{array}$ & 0.28 & 1.13 & 0.17 & -0.77 & -0.50 \\
\hline & 10 & $\begin{array}{c}5.58 \\
(1.24)\end{array}$ & 1.13 & 0.33 & $\begin{array}{c}5.50 \\
(0.80)\end{array}$ & 0.15 & 0.50 & 0.67 & -0.44 & -0.63 \\
\hline & 11 & $\begin{array}{c}5.08 \\
(1.78)\end{array}$ & 1.50 & 0.00 & $\begin{array}{c}5.25 \\
(1.29)\end{array}$ & 0.25 & 1.13 & 0.17 & -0.49 & -0.38 \\
\hline & 12 & $\begin{array}{c}4.75 \\
(1.54)\end{array}$ & 1.00 & 0.33 & $\begin{array}{c}4.92 \\
(0.79)\end{array}$ & 0.16 & 0.63 & 0.33 & -0.75 & -0.38 \\
\hline
\end{tabular}


Table A1. Cont.

\begin{tabular}{|c|c|c|c|c|c|c|c|c|c|c|}
\hline \multirow{2}{*}{ Work Type } & \multirow{2}{*}{$\begin{array}{c}\text { Control } \\
\text { Measure 1) }\end{array}$} & \multicolumn{3}{|c|}{ Delphi Round $1(n=12)$} & \multicolumn{4}{|c|}{ Delphi Round $2(n=12)$} & \multirow{2}{*}{$\begin{array}{l}\text { SD } \\
\text { Change }\end{array}$} & \multirow{2}{*}{$\begin{array}{l}\text { Conv } \\
\text { Change }\end{array}$} \\
\hline & & $\begin{array}{c}\mathrm{M} \\
\text { (SD) }\end{array}$ & $\begin{array}{l}\text { Conv } \\
(\leq 1)\end{array}$ & $\begin{array}{l}\text { CVR } \\
(>56)\end{array}$ & $\begin{array}{c}\mathrm{M} \\
\text { (SD) }\end{array}$ & $\begin{array}{c}\text { Stability } \\
(<0.8)\end{array}$ & $\begin{array}{l}\text { Conv } \\
(\leq 1)\end{array}$ & $\begin{array}{c}\text { CVR } \\
(>0.56)\end{array}$ & & \\
\hline \multirow{12}{*}{$\begin{array}{c}\text { Exterior } \\
\text { wall wok }\end{array}$} & 1 & $\begin{array}{c}4.08 \\
(2.11)\end{array}$ & 1.63 & -0.33 & $\begin{array}{c}4.00 \\
(1.13)\end{array}$ & 0.28 & 0.63 & -0.50 & -0.98 & -1.00 \\
\hline & 2 & $\begin{array}{c}3.83 \\
(2.21)\end{array}$ & 1.75 & -0.33 & $\begin{array}{c}3.50 \\
(1.13)\end{array}$ & 0.32 & 1.13 & -0.50 & -1.08 & -0.63 \\
\hline & 3 & $\begin{array}{c}3.33 \\
(2.02)\end{array}$ & 1.25 & -0.50 & $\begin{array}{c}3.08 \\
(1.13)\end{array}$ & 0.37 & 1.00 & -1.00 & -0.89 & -0.25 \\
\hline & 4 & $\begin{array}{c}3.42 \\
(1.93)\end{array}$ & 0.88 & -0.50 & $\begin{array}{c}3.42 \\
(0.67)\end{array}$ & 0.20 & 0.50 & -0.83 & -1.26 & -0.38 \\
\hline & 5 & $\begin{array}{c}4.25 \\
(1.76)\end{array}$ & 1.13 & 0.00 & $\begin{array}{c}4.00 \\
(0.95)\end{array}$ & 0.24 & 1.00 & -0.17 & -0.81 & -0.13 \\
\hline & 6 & $\begin{array}{c}4.00 \\
(1.65)\end{array}$ & 1.00 & -0.33 & $\begin{array}{c}3.92 \\
(0.90)\end{array}$ & 0.23 & 1.00 & -0.33 & -0.75 & 0.00 \\
\hline & 7 & $\begin{array}{c}4.00 \\
(1.65)\end{array}$ & 1.00 & -0.33 & $\begin{array}{c}4.00 \\
(0.85)\end{array}$ & 0.21 & 1.00 & -0.33 & -0.80 & 0.00 \\
\hline & 8 & $\begin{array}{c}4.42 \\
(1.98)\end{array}$ & 1.25 & 0.00 & $\begin{array}{c}4.75 \\
(1.06)\end{array}$ & 0.22 & 0.63 & -0.17 & -0.92 & -0.63 \\
\hline & 9 & $\begin{array}{c}3.67 \\
(1.92)\end{array}$ & 1.50 & -0.33 & $\begin{array}{c}3.50 \\
(1.09)\end{array}$ & 0.31 & 0.63 & -0.67 & -0.84 & -0.88 \\
\hline & 10 & $\begin{array}{c}4.50 \\
(1.93)\end{array}$ & 1.50 & 0.17 & $\begin{array}{c}4.58 \\
(1.08)\end{array}$ & 0.24 & 0.63 & 0.33 & -0.85 & -0.88 \\
\hline & 11 & $\begin{array}{c}3.50 \\
(2.11)\end{array}$ & 1.63 & -0.33 & $\begin{array}{c}3.42 \\
(1.56)\end{array}$ & 0.46 & 1.50 & -0.33 & -0.55 & -0.13 \\
\hline & 12 & $\begin{array}{l}5.00 \\
(2.00)\end{array}$ & 2.00 & 0.33 & $\begin{array}{c}5.00 \\
(1.48)\end{array}$ & 0.30 & 1.13 & 0.33 & -0.52 & -0.88 \\
\hline \multirow{12}{*}{ Plaster work } & 1 & $\begin{array}{c}3.83 \\
(2.21)\end{array}$ & 1.63 & -0.17 & $\begin{array}{c}3.50 \\
(1.38)\end{array}$ & 0.39 & 1.50 & -0.33 & -0.83 & -0.13 \\
\hline & 2 & $\begin{array}{c}3.83 \\
(2.21)\end{array}$ & 2.13 & -0.17 & $\begin{array}{c}3.92 \\
(1.38)\end{array}$ & 0.35 & 1.50 & 0.00 & -0.83 & -0.63 \\
\hline & 3 & $\begin{array}{c}3.17 \\
(1.80)\end{array}$ & 1.13 & -0.67 & $\begin{array}{c}2.83 \\
(1.38)\end{array}$ & 0.49 & 0.63 & -1.00 & -0.42 & -0.50 \\
\hline & 4 & $\begin{array}{c}3.00 \\
(1.86)\end{array}$ & 1.25 & -0.50 & $\begin{array}{c}2.75 \\
(1.06)\end{array}$ & 0.38 & 0.63 & -0.83 & -0.80 & -0.63 \\
\hline & 5 & $\begin{array}{c}3.50 \\
(1.78)\end{array}$ & 0.63 & -0.67 & $\begin{array}{c}3.42 \\
(0.51)\end{array}$ & 0.15 & 0.50 & -1.00 & -1.27 & -0.13 \\
\hline & 6 & $\begin{array}{c}3.50 \\
(1.83)\end{array}$ & 1.00 & -0.67 & $\begin{array}{c}3.17 \\
(1.11)\end{array}$ & 0.35 & 1.00 & -0.83 & -0.72 & 0.00 \\
\hline & 7 & $\begin{array}{c}3.83 \\
(1.90)\end{array}$ & 0.88 & -0.50 & $\begin{array}{c}3.75 \\
(0.62)\end{array}$ & 0.17 & 0.50 & -0.83 & -1.28 & -0.38 \\
\hline & 8 & $\begin{array}{c}3.42 \\
(1.62)\end{array}$ & 1.13 & -0.33 & $\begin{array}{c}3.75 \\
(0.97)\end{array}$ & 0.26 & 1.00 & -0.33 & -0.66 & -0.13 \\
\hline & 9 & $\begin{array}{c}3.42 \\
(1.98)\end{array}$ & 1.50 & -0.33 & $\begin{array}{c}3.25 \\
(1.29)\end{array}$ & 0.40 & 1.13 & -0.50 & -0.69 & -0.38 \\
\hline & 10 & $\begin{array}{c}4.92 \\
(1.73)\end{array}$ & 1.13 & 0.17 & $\begin{array}{c}5.00 \\
(0.95)\end{array}$ & 0.19 & 0.63 & 0.33 & -0.78 & -0.50 \\
\hline & 11 & $\begin{array}{c}4.75 \\
(1.54)\end{array}$ & 1.00 & 0.00 & $\begin{array}{c}4.75 \\
(0.75)\end{array}$ & 0.16 & 0.50 & 0.17 & -0.79 & -0.50 \\
\hline & 12 & $\begin{array}{c}3.67 \\
(1.87)\end{array}$ & 1.50 & 0.00 & $\begin{array}{c}3.83 \\
(1.34)\end{array}$ & 0.35 & 1.13 & 0.00 & -0.54 & -0.38 \\
\hline \multirow{8}{*}{$\begin{array}{l}\text { Painting } \\
\text { work }\end{array}$} & 1 & $\begin{array}{c}4.00 \\
(2.26)\end{array}$ & 2.00 & 0.00 & $\begin{array}{c}3.75 \\
(1.60)\end{array}$ & 0.43 & 1.50 & -0.17 & -0.65 & -0.50 \\
\hline & 2 & $\begin{array}{c}4.17 \\
(2.41)\end{array}$ & 2.13 & 0.00 & $\begin{array}{c}3.83 \\
(1.60)\end{array}$ & 0.42 & 1.63 & -0.17 & -0.80 & -0.50 \\
\hline & 3 & $\begin{array}{c}2.33 \\
(1.87)\end{array}$ & 1.50 & -0.67 & $\begin{array}{c}2.25 \\
(1.60)\end{array}$ & 0.71 & 1.50 & -1.00 & -0.27 & 0.00 \\
\hline & 4 & $\begin{array}{c}2.92 \\
(2.07)\end{array}$ & 2.00 & -0.33 & $\begin{array}{c}2.75 \\
(1.76)\end{array}$ & 0.64 & 1.63 & -0.50 & -0.30 & -0.38 \\
\hline & 5 & $\begin{array}{c}3.25 \\
(2.01)\end{array}$ & 1.25 & -0.50 & $\begin{array}{c}2.92 \\
(0.79)\end{array}$ & 0.27 & 0.63 & -1.00 & -1.21 & -0.63 \\
\hline & 6 & $\begin{array}{l}3.33 \\
(2.10)\end{array}$ & 1.63 & -0.33 & $\begin{array}{c}3.17 \\
(1.34)\end{array}$ & 0.42 & 1.13 & -0.50 & -0.77 & -0.50 \\
\hline & 7 & $\begin{array}{c}3.42 \\
(2.23)\end{array}$ & 1.38 & -0.50 & $\begin{array}{c}3.17 \\
(1.03)\end{array}$ & 0.33 & 1.00 & -0.83 & -1.20 & -0.38 \\
\hline & 8 & $\begin{array}{c}3.50 \\
(1.98)\end{array}$ & 1.75 & -0.33 & $\begin{array}{c}3.75 \\
(1.60)\end{array}$ & 0.43 & 1.50 & -0.17 & -0.37 & -0.25 \\
\hline
\end{tabular}


Table A1. Cont.

\begin{tabular}{|c|c|c|c|c|c|c|c|c|c|c|}
\hline \multirow{2}{*}{ Work Type } & \multirow{2}{*}{$\begin{array}{c}\text { Control } \\
\text { Measure 1) }\end{array}$} & \multicolumn{3}{|c|}{ Delphi Round $1(n=12)$} & \multicolumn{4}{|c|}{ Delphi Round $2(n=12)$} & \multirow{2}{*}{$\begin{array}{l}\text { SD } \\
\text { Change }\end{array}$} & \multirow{2}{*}{$\begin{array}{l}\text { Conv } \\
\text { Change }\end{array}$} \\
\hline & & $\begin{array}{c}\mathrm{M} \\
\text { (SD) }\end{array}$ & $\begin{array}{l}\text { Conv } \\
(\leq 1)\end{array}$ & $\begin{array}{l}\text { CVR } \\
(>56)\end{array}$ & $\begin{array}{c}\mathrm{M} \\
\text { (SD) }\end{array}$ & $\begin{array}{l}\text { Stability } \\
(<0.8)\end{array}$ & $\begin{array}{l}\text { Conv } \\
(\leq 1)\end{array}$ & $\begin{array}{c}\text { CVR } \\
(>0.56)\end{array}$ & & \\
\hline & 9 & $\begin{array}{c}3.25 \\
(1.82)\end{array}$ & 1.63 & -0.33 & $\begin{array}{c}3.42 \\
(1.38)\end{array}$ & 0.40 & 1.50 & -0.33 & -0.44 & -0.13 \\
\hline & 10 & $\begin{array}{c}4.33 \\
(2.15)\end{array}$ & 1.63 & 0.17 & $\begin{array}{c}4.67 \\
(1.07)\end{array}$ & 0.23 & 0.25 & 0.50 & -1.07 & -1.38 \\
\hline & 11 & $\begin{array}{c}4.42 \\
(1.88)\end{array}$ & 1.13 & -0.17 & $\begin{array}{c}4.58 \\
(0.79)\end{array}$ & 0.17 & 0.50 & -0.17 & -1.09 & -0.63 \\
\hline & 12 & $\begin{array}{c}5.75 \\
(1.54) \\
\end{array}$ & 0.75 & 0.50 & $\begin{array}{c}6.08 \\
(0.79) \\
\end{array}$ & 0.13 & 0.13 & 0.83 & -0.75 & -0.63 \\
\hline \multirow{12}{*}{$\begin{array}{l}\text { Landscaping } \\
\text { work }\end{array}$} & 1 & $\begin{array}{c}4.25 \\
(2.05)\end{array}$ & 1.50 & -0.17 & $\begin{array}{c}4.00 \\
(1.28)\end{array}$ & 0.32 & 0.75 & -0.50 & -0.77 & -0.75 \\
\hline & 2 & $\begin{array}{l}3.33 \\
(2.15)\end{array}$ & 1.75 & -0.33 & $\begin{array}{c}2.75 \\
(1.28)\end{array}$ & 0.47 & 0.50 & -0.83 & -0.87 & -1.25 \\
\hline & 3 & $\begin{array}{c}5.17 \\
(1.99)\end{array}$ & 1.63 & 0.33 & $\begin{array}{c}5.00 \\
(1.28)\end{array}$ & 0.26 & 1.00 & 0.00 & -0.71 & -0.63 \\
\hline & 4 & $\begin{array}{l}5.00 \\
(2.04)\end{array}$ & 1.25 & 0.33 & $\begin{array}{c}5.00 \\
(1.04)\end{array}$ & 0.21 & 1.00 & 0.00 & -1.00 & -0.25 \\
\hline & 5 & $\begin{array}{c}5.58 \\
(1.24)\end{array}$ & 0.63 & 0.67 & $\begin{array}{c}5.58 \\
(0.67)\end{array}$ & 0.12 & 0.50 & 1.00 & -0.57 & -0.13 \\
\hline & 6 & $\begin{array}{c}5.33 \\
(1.37)\end{array}$ & 1.13 & 0.33 & $\begin{array}{c}5.00 \\
(0.95)\end{array}$ & 0.19 & 1.00 & 0.17 & -0.42 & -0.13 \\
\hline & 7 & $\begin{array}{c}5.25 \\
(1.48)\end{array}$ & 0.50 & 0.67 & $\begin{array}{c}5.58 \\
(0.67)\end{array}$ & 0.12 & 0.50 & 1.00 & -0.82 & 0.00 \\
\hline & 8 & $\begin{array}{c}5.42 \\
(1.51)\end{array}$ & 0.50 & 0.67 & $\begin{array}{c}5.58 \\
(0.51)\end{array}$ & 0.09 & 0.50 & 1.00 & -0.99 & 0.00 \\
\hline & 9 & $\begin{array}{c}5.92 \\
(0.90)\end{array}$ & 0.25 & 0.83 & $\begin{array}{c}6.08 \\
(0.29)\end{array}$ & 0.05 & 0.00 & 1.00 & -0.61 & -0.25 \\
\hline & 10 & $\begin{array}{c}5.33 \\
(1.72)\end{array}$ & 0.75 & 0.50 & $\begin{array}{c}5.75 \\
(0.62)\end{array}$ & 0.11 & 0.50 & 1.00 & -1.10 & -0.25 \\
\hline & 11 & $\begin{array}{c}3.67 \\
(1.61)\end{array}$ & 1.13 & -0.33 & $\begin{array}{c}3.83 \\
(0.83)\end{array}$ & 0.22 & 0.63 & -0.50 & -0.78 & -0.50 \\
\hline & 12 & $\begin{array}{c}5.08 \\
(1.31)\end{array}$ & 1.00 & 0.17 & $\begin{array}{l}5.00 \\
(0.85)\end{array}$ & 0.17 & 1.00 & 0.33 & -0.46 & 0.00 \\
\hline \multirow{12}{*}{$\begin{array}{l}\text { Demolition } \\
\text { work }\end{array}$} & 1 & $\begin{array}{c}5.50 \\
(2.02)\end{array}$ & 1.00 & 0.67 & $\begin{array}{c}6.17 \\
(0.83)\end{array}$ & 0.14 & 0.63 & 1.00 & -1.19 & -0.38 \\
\hline & 2 & $\begin{array}{c}5.92 \\
(1.44)\end{array}$ & 0.63 & 0.83 & $\begin{array}{c}6.33 \\
(0.83)\end{array}$ & 0.13 & 0.50 & 1.00 & -0.61 & -0.13 \\
\hline & 3 & $\begin{array}{c}6.58 \\
(0.67)\end{array}$ & 0.50 & 1.00 & $\begin{array}{c}6.67 \\
(0.83)\end{array}$ & 0.13 & 0.50 & 1.00 & 0.17 & 0.00 \\
\hline & 4 & $\begin{array}{c}6.00 \\
(1.71)\end{array}$ & 0.50 & 0.83 & $\begin{array}{c}6.42 \\
(0.51)\end{array}$ & 0.08 & 0.50 & 1.00 & -1.19 & 0.00 \\
\hline & 5 & $\begin{array}{c}5.58 \\
(1.16)\end{array}$ & 0.63 & 0.83 & $\begin{array}{c}5.75 \\
(0.62)\end{array}$ & 0.11 & 0.50 & 1.00 & -0.54 & -0.13 \\
\hline & 6 & $\begin{array}{c}5.33 \\
(1.15)\end{array}$ & 0.50 & 0.67 & $\begin{array}{c}5.42 \\
(0.51)\end{array}$ & 0.10 & 0.50 & 1.00 & -0.64 & 0.00 \\
\hline & 7 & $\begin{array}{c}5.08 \\
(1.51)\end{array}$ & 0.63 & 0.50 & $\begin{array}{c}5.50 \\
(0.52)\end{array}$ & 0.09 & 0.50 & 1.00 & -0.98 & -0.13 \\
\hline & 8 & $\begin{array}{c}5.08 \\
(2.07)\end{array}$ & 1.25 & 0.50 & $\begin{array}{c}5.83 \\
(0.94)\end{array}$ & 0.16 & 1.00 & 1.00 & -1.13 & -0.25 \\
\hline & 9 & $\begin{array}{c}6.42 \\
(1.00)\end{array}$ & 0.50 & 0.83 & $\begin{array}{c}6.58 \\
(0.51)\end{array}$ & 0.08 & 0.50 & 1.00 & -0.48 & 0.00 \\
\hline & 10 & $\begin{array}{c}5.50 \\
(1.83)\end{array}$ & 1.25 & 0.50 & $\begin{array}{c}6.25 \\
(0.87)\end{array}$ & 0.14 & 0.63 & 1.00 & -0.97 & -0.63 \\
\hline & 11 & $\begin{array}{c}4.33 \\
(2.31)\end{array}$ & 1.75 & 0.17 & $\begin{array}{c}4.67 \\
(1.15)\end{array}$ & 0.25 & 0.75 & 0.33 & -1.15 & -1.00 \\
\hline & 12 & $\begin{array}{c}5.58 \\
(1.51)\end{array}$ & 0.38 & 0.50 & $\begin{array}{c}6.17 \\
(0.39)\end{array}$ & 0.06 & 0.00 & 1.00 & -1.12 & -0.38 \\
\hline
\end{tabular}

(1) Control measures: 1. Dustproof facility, 2. Dust-collecting facility, 3. Water spray facility, 4. Wheel-washing facility, 5. Control of load capacity, 6. Low-speed driving, 7. Horizontal loading, 8. Road pavement, 9. Spraying water, 10. Cleaning, 11. Indoor work, and 12. The suspension of work when wind speed was high; (2) Shaded parts: selected fugitive dust control measures. 


\section{References}

1. National Institute of Environmental Research. 2013 National Air Pollutant Emissions; National Institute of Environmental Research: Incheon, Korea, 2015.

2. Korea Legislation Research Institute. Standards for installation and necessary measures to control fugitive dust generation. In Enforcement Decree of the Clean Air Conservation Act; Korea Legislation Research Institute: Seoul, Korea, 1997.

3. The Ministry of Environment. Status of civil complaint related to fugitive dust. Available online: http:/ / stat.me.go.kr/nesis/mesp2/webStatistics/stat_main.jsp?tblID=DT_106N_99_2800012\&inq_gubun= 1\&lang=kor\&list_id=\&l_interval=2 (accessed on 5 December 2017).

4. National Institute of Environmental Research. 2016: Annual Report of Air Quality in Korea; National Institute of Environmental Research: Incheon, Korea, 2015.

5. Hsu, A.; Esty, D.C.; Levy, M.A.; de Sherbinin, A. 2016 Environmental Performance Index (EPI); Yale University: New Haven, CT, USA, 2016.

6. Statistics Korea. Air Pollution of Major City. Available online: http://www.index.go.kr/potal/main/ EachDtlPageDetail.do?idx_cd=2789 (accessed on 5 December 2017).

7. Air Quality Research Division; Climate and Air Quality Research Department. Study on the Characteristic on Physical and Chemical Properties of PM2.5; National Institute of Environmental Research: Incheon, Korea, 2009.

8. Yu, H.J.; Han, K.Y.; Kwak, K.S.; Kim, J.S.; Yang, K.Y. A study on the actual condition and effect of dust scattering in construction field. J. Korea Inst. Build. Constr. 2004, 4, 109-116. [CrossRef]

9. Choi, Y.J.; Hong, J.S. A Study on Environmental Management of Construction Sites: Focusing on Air Pollution and Noise; The Seoul Institute: Seoul, Korea, 2015.

10. U.S Environmental Protection Agency. Basics of SIP Requirements. Available online: https://www.epa.gov/ ozone-pollution/basics-sip-requirements (accessed on 18 June 2017).

11. Martin Kay, P.E.; Baez, A.; Engineer, S.A.Q.; Lange, H.; Huynh, K.; Hasan, S. Rule 403: Fugitive dust. In South Coast Air Quality Management District; SCAQMD: Los Angeles, CA, USA, 2005.

12. UK Environment Agency. Office access and opening times. Available online: https://www.gov.uk/ environment-agency (accessed on 18 June 2017).

13. Mayor of London. The Control of Dust and Emissions during Construction and Demolition. Supplementary Planning Guidance; Greater London Authority: London, UK, 2014.

14. Kinsey, J.S.; Linna, K.J.; Squier, W.C.; Muleski, G.E.; Cowherd Jr., C. Characterization of the fugitive particulate emissions from construction mud/dirt carryout. J. Air Waste Manag. Assoc. 2004, 54, 1394-1404. [CrossRef] [PubMed]

15. Muleski, G.E.; Cowherd Jr., C.; Kinsey, J.S. Particulate emissions from construction activities. J. Air Waste Manag. Assoc. 2005, 55, 772-783. [CrossRef] [PubMed]

16. Seo, Y.H. Development of construction site source profile by a chemical analysis of PM10 collected at the construction site. J. Korea Soc. Environ. Adm. 2013, 19, 67-72.

17. Kohlman-Rabbani, E.R.; Shapira, A.; Martins, A.R.B.; Barkokebas, JR. Characterization and Evaluation of dust on building construction site in Brazil. Open Occup. Health Saf. J. 2014, 5, 1-8. [CrossRef]

18. Thorpe, A.; Ritchie, A.S.; Gibson, M.J.; Brown, R.C. Measurements of the effectiveness of dust control on cut-off saws used in the construction industry. Ann. Occup. Hyg. 1999, 43, 443-456. [CrossRef]

19. Evelyn, T.N.; Simone, H.; Ton, S.; Judith, S.; Friso, S.; Mieke, L.; Dick, H. Dust control measures in the construction industry. Ann. Occup. Hyg. 2003, 47, 211-218.

20. Zuo, J.; Rameezdeen, R.; Hagger, M.; Ding, Z. Dust pollution control on construction site: Awareness and self-responsibility of managers. J. Clean. Prod. 2017, 166, 312-320. [CrossRef]

21. Ministry of Land, Infrastructure and Transportation. Construction Work Standard Specifications 2013. Available online: http://www.law.go.kr/admRulLsInfoP.do?admRulSeq=2200000064672 (accessed on 20 June 2017).

22. Linstone, H.A.; Turoff, M. The Delphi Method: Techniques and Applications; Addison-Wesley Publishing Company: Boston, MA, USA, 1975.

23. Yu, S.K.; Kang, K.S. The current situation and direction of national and international news agencies': Disaster-related reporting, using Delphi method for professionals. Broadcast. Telecommun. Stud. 2011, 76, 140-169. 
24. Lee, J.S. Delphi Methodology; Kyoyookbook: Seoul, Korea, 2006.

25. Dalkey, N.C. The Delphi method: An Experimental Study of Group Opinion; Rand Corporation: Santa Monica, CA, USA, 1969.

26. Anderson, D. Strand of System: The Philosophy of Charles Peirce; Purdue University Press: West Lafayette, IN, USA, 1995.

27. Kang, Y.J. Understanding and Practice of Delphi Technique; Korea Employment Agency for the Disables: Seongnam, Korea, 2008.

28. Noh, S.Y. Delphi Technique: Predict the Future with Professional Insights; Korea Research Institute for Human Settlements: Anyang, Korea, 2013.

29. Jang, C.Y. A Preliminary Study on the Development of the Indicators for the Fear of Crime. Police Sci. J. 2014, 9, 93-120.

30. De Vet, E.; Brug, J.; De Nooijer, J.; Dijkstra, A.; De Vries, N.K. Determinants of forward stage transitions: A Delphi study. Health Educ. Res. 2005, 20, 195-205. [CrossRef] [PubMed]

31. Hahn, E.J.; Rayens, M.K. Consensus for tobacco policy among former state legislators using the policy Delphi method. Tob. Control 1999, 8, 137-140. [CrossRef] [PubMed]

32. Raskin, M.S. The Delphi study in field instruction revisited: Expert consensus on issues and research priorities. J. Soc. Work Educ. 1994, 30, 75-89. [CrossRef]

33. Scheibe, M.; Skutsch, M.; Schofer, J. Experiments in Delphi methodology. In Delphi Method: Techniques and Applications, 1st ed.; Linstone, H.A., Turoff, M., Eds.; Addison-Wesley Publishing Company: Boston, MA, USA, 1975.

34. Lawshe, C.H. A quantitative approach to content validity. Pers. Psychol. 1975, 28, 563-575. [CrossRef]

(C) 2018 by the authors. Licensee MDPI, Basel, Switzerland. This article is an open access article distributed under the terms and conditions of the Creative Commons Attribution (CC BY) license (http:// creativecommons.org/licenses/by/4.0/). 